\title{
The Right to Work in Article 27 Of The UN Convention on The Rights of Persons With Disabilities: Towards an Inclusive Employment ${ }^{1}$
}

\author{
Hak Atas Pekerjaan pada Pasal 27 Konvensi Perserikatan Bangsa-Bangsa \\ tentang Hak-Hak Penyandang Disabilitas: \\ Menuju Dunia Kerja Yang Inklusif
}

\author{
Yeni Rosdianti ${ }^{2}$ \\ National University of Ireland, Galway, Republic of Ireland \\ Email: y.rosdianti1@nuigalway.ie \\ Naskah diterima: 30 April 2018 \\ Naskah direvisi: 14 September 2018 \\ Naskah diterbitkan: 1 November 2018
}

\begin{abstract}
Abstrak
"Bekerja" memegang peranan penting dalam kehidupan umat manusia, tidak hanya dalam arti ekonomi namun juga bermakna pemuliaan martabat manusia. Bekerja, selain dapat menjamin penghidupan, juga merupakan alat pencapaian inklusi dan partisipasi setara dalam relasi sosial. Martabat manusia menjadi landasan prinsip kesetaraan untuk membentuk masyarakat inklusif dimana kelompok rentan secara penuh dihormati hak-haknya hingga dapat berpartisipasi secara maksimal di tengah-tengah masyarakat. Hak Asasi Manusia (HAM) memegang peranan penting dalam hal ini, khususnya terkait dengan pemajuan hak-hak penyandang disabilitas dalam kerangka prinsip-prinsip kesetaraan dan non-diskriminasi. Konvensi Persatuan Bangsa-Bangsa tentang Hak-hak Penyandang Disabilitas (Atau selanjutnya disebut CRPD) yang telah diratifikasi oleh Pemerintah Indonesia pada tahun 2011, meletakkan dasar yang kokoh bagi perlindungan hak-hak penyandang disabilitas dalam penerapan kaidah-kaidah dasar HAM. Konvensi ini dianggap sebagai model disabilitas terkini yang mengacu pada pendekatan HAM. Terkait dengan hak atas pekerjaan khususnya untuk penyandang disabilitas, pasal 27 CRPD meletakkannya dalam rangka mencapai dunia kerja yang inklusif dan setara. Untuk itu, CRPD mendorong langkahlangkah positif (positive measures) sebagai sarana menyingkirkan hambatan struktural yang dihadapi oleh penyandang disabilitas selama ini.
\end{abstract}

Kata kunci: Penyandang disabilitas, hak atas pekerjaan, hak asasi manusia, CRPD

\begin{abstract}
Work is essential for every human being, not only in economic meaning, but also in the sense of dignity. It guarantees to sustain life and also a tool of inclusion as a vital social relationship in a society. Dignity outlines the principle of equality to form an inclusive society. Thereunto, a social inclusion is an objective whereby disadvantaged groups are fully respected yet enjoying their maximum equal participation in the society. Social inclusion is the ultimate goal of disability movements. In this respect, human rights play its crucial roles to acknowledge the rights of persons with disabilities which centered on an equality and non-discrimination principles. United Nation Convention on the Rights of Persons with Disabilities (hereinafter CRPD), that has been ratified by Indonesian Government in 2011, draws the enormous attention specifically on the protection of the persons with disabilities within a broad application of general human rights norms. This treaty is considered as a modern human rights model of disability. With respect to work and

\footnotetext{
1 The research for this article was undertaken in partial fulfilment of the requirements for the degree of $\mathrm{PhD}$ at the University of Ireland, Galway, Republic Ireland, supervised by Dr. Lucy-Ann Buckley and Professor Gerard Quinn (funded by Endowmend Fund for Education, Government of Indonesia).

2 Senior Researcher of the National Commission on Human Rights Republic of Indonesia (Komnas HAM)
} 
employment for persons with disability, article 27 elucidates a development of the right to work of persons with disabilities to aim an inclusive employment. For this reasons, CRPD acknowledges the positive measures to be applied as the vigorous means in removing structural barriers to date.

Keywords: persons with disabilities, the right to work, human rights, CRPD

\section{Introduction}

Given the social and economic importance of work, it is not surprising that the right to work received early protection in human rights framework. Since Universal Declaration of Human Rights (UDHR) was set up in 1948, the concept of right to work has been built in the entire development of human rights framework. In this sense, the right to work was one of denotative device of economic, social and cultural rights. Article 23 (1) of UDHR clearly states "Everyone has the right to work, to free choice of employment, to just and favourable conditions of work and to protection against unemployment." This notion of the right to work includes not only "to get a job" but also a freedom to choose any kind of preferred work. It also highlights a just and favourable protection to the people and their family.

Everyone who works has the right to just and favourable remuneration ensuring for himself and his family an existence worthy of human dignity, and supplemented, if necessary, by other means of social protection. ${ }^{3}$

In this respect, the right to work is simply perceived not only in the 'economic survival' but much broader, it introduced the development concept of work as an existence of human dignity as well as a social protection of human being. Then, the next Article guarantees the fulfilment of standard of living by the right to security "in the event of unemployment, sickness, disability,

Article 23 (3) of 'The Universal Declaration of Human Rights | United Nations' (1948) < http://www.un.org/en/ universal-declaration-human-rights/>., accessed 9 June 2016 widowhood, old age or other lack of livelihood in circumstances beyond his control." ${ }^{4}$ The rights must be secured in both common and unexpected situation, as mentioned above in the Declaration. The Declaration by all means sums up the right to life as "an existence worthy of human dignity," ${ }^{5}$ which therefore has to be guaranteed in any situation. The above provisions are based on the equality and nondiscrimination principles, which means that disadvantaged groups are to be included in the protection. Disability, as stated in the Article 25 of the UDHR, is admitted as one of the causes of the risk of living below standard.

Besides experiencing discrimination in most cases $^{6}$, the problem of the fulfilment of right to work of persons with disabilities to date is on the lack of awareness. It is derived from the old paradigm perceiving disability as an individual problem instead of removing structural barriers. The rights based approach raised to address this typical problem on discrimination generally resulted from the stigma and stereotype surround disability. This paper highlights the article 27 of the UN-CRPD that enormously based on human rights perspective of how the right to work of persons with disabilities has to be protected. As this article 27 is considered as the latest human rights instrument adopted on the right to work specifically for persons with disabilities.

This paper explores the idea of the core elements of the article 27 and also touch on the recent development of the international arena particularly on the latest implementation by the states parties and the response of the committee of CRPD in their concluding observations. With regard to the equality for persons with disabilities, the latest general comment no.6 of CRPD (2018) on Equality and Non-discrimination is taken

article 25 'The Universal Declaration of Human Rights | United Nations' <http://www.un.org/en/universaldeclaration-human-rights/> accessed 15 April 2016. article 23 (3) 'The Universal Declaration of Human Rights | United Nations' (n 5).

Arlene S Kanter, "A Comparative View of Equality Under the UN Convention on the Rights of PERSONS with Disabilities and the Disability Laws of the United States and Canada", Windsor Yearbook of Access to Justice, Vol. 32, 2015, p. 65-90. 
into account. Additionally, this paper is also pertaining on the relation of genuine content of the right to work in Article 27 with the UN recent blueprint of Sustainable Development Goals (target by 2030) to achieve a better and more sustainable future for all. The purpose of this study is to advance understanding on the conceptual model of human rights based approach as enshirend in the article 27 of UNCRPD into its practice to achieve an inclusive employment for persons with disabilities in equality basis. This type of human rights approach is well established on looking at disability ground However, the exploration of article 27 of the UN-CRPD on achieving inclusive employment for persons with disability in equality context that vindicating positive measures has not been extensively studied.

\section{Discussion}

This part will reflect the importance of the right to work in light of social inclusion, equality and non-discrimination, as well as the normative contents underlying the article 27 . In addition, it will also express how the preferential treatments/positive measures would be a tool to carry out the substantive equality for persons with disabilities towards the facto equality in the employment context.

\section{A. Work and social inclusion}

Paid employment is a substantial line towards social inclusion. ${ }^{7}$ There is an immense indication which links unemployment to social isolation, loss of confidence, lowered self esteem, poor mental and physical health, and increase risk of suicide and premature death. ${ }^{8}$ Meaningful employment offers many incentives $^{9}$ in particular for persons with

Helena Rose, Anna Daiches, and Jo Potier, 'Meaning of Social Inclusion to Young People Not in Employment, Education or Training', Journal of Community \& Applied Social Psychology 256, vol. 22, Issue 3, May 2012 p.256268. 257.

$8 \quad$ Ibid.

$9 \quad$ See also Rosemary Lysaght and others, "Inclusion Through Work and Productivity for Persons with Intellectual and Developmental Disabilities", Journal of Applied Research in Intellectual Disabilities, Vol. 30, 2017, p. 922. disabilities to aim living independently. For disadvantaged groups in the society, work is most of the time characterized by inequality and exclusion ${ }^{10}$ where persons with disabilities have more limitation to access labour force. ${ }^{11}$ Sadly in the capitalist welfare state, for example, perception on a lack of inclusion of persons with disabilities in employment is taken for granted. ${ }^{12}$ The existing stigmas lead to social barriers encountered by persons with disabilities to entering a labour force. ${ }^{13}$ Furthermore, dominant norms of the society that lead to the salient of social determination ${ }^{14}$ (employers in this context) define their own criteria to recruit employees, which in most cases are not disabledfriendly. ${ }^{15}$ Therefore, persons with disabilities tend to be excluded since they cannot meet the criteria set by the employers, for example, the criterion of "physical and mental healthy". This criterion is commonly defined as "posses no disability." In this regard, the dominant norms are likely underlying the perception that disability has no place in the employment.

The idea of permeating labour force for persons with disabilities strive against dominant norms, stereotype and prejudice, while disregarded capability and even perception on 'lack of capacity.' The barriers might be different for each type of disability, ${ }^{16}$ yet the

10 Rannveig Traustadóttir, Work, Disability, and Social Inclusion: The Promise and Problematics of EU Disability Policy, in Marjorie L DeVault (ed), People at Work: Life, Power, and Social Inclusion in the New Economy, New York: NYU Press, 2008, p. 75.

11 See Eduardo Daniel Joly and María Pía Venturiello, "Persons with Disabilities: Entitled to Beg, Not to Work. The Argentine Case", Journal of Critical Sociology, Vol. 39 Issue 3, July 2012, p. 325-347.

12 Rannveig Traustadóttir, Work, Disability, and Social Inclusion: The Promise and Problematics of EU Disability Policy, in DeVault (n 12) 75.

13 Rannveig Traustadóttir, Work, Disability, and Social Inclusion: The Promise and Problematics of EU Disability Policy, in Ibid 89.

14 Paul T Jaeger and Cynthia Ann Bowman, Understanding Disability: Inclusion, Access, Diversity, and Civil Rights, London: Greenwood Publishing Group, 2005, p. 6.

15 Ibid.

16 Lisa Waddington, Gerard Quinn and Eilionóir Flynn, European Yearbook of Disability Law, Belgium: Intersentia Limited, 2014, p. 11. 
effect remains the same: limit and 'disabling' them to participate in labour force.

Among the greatest barriers faced by adults with disabilities is the lack of opportunities for fulfilling career trajectories consistent with their full capacity. ${ }^{17}$

It has captured a narrow link between employment rate and disability. ${ }^{18}$ It indicates that persons with disabilities are in a vulnerable situation, as they are more affected by unemployment than their nondisabled counterparts. ${ }^{19}$ This circumstance should encourage definite law and policies assigned to promote employment for persons with disabilities to achieve real equality in the society. The acknowledgment of diversity (noting disability as diversity of the society) requires collective action. ${ }^{20}$

Another discussion of an unaddressed perspective was regarding different interests between state and business entity. Providing decent work for persons with disabilities to some extent can reduce the budget of social benefit for unemployment, however most employers may not perceive it as their own interest. ${ }^{21}$ Accordingly, an establishment of shared vision between state and business entity should be in place. In a broader sense, lack of involvement of the business entity in the spirit of budget alleviation will result to multiplier effects on the whole economic and social development.

17 Jody Heymann, Michael Ashley Stein, and Gonzalo Moreno, Disability, Employment, and Inclusion Worldwide, London: Oxford University Press, p. 1.

18 Rannveig Traustadóttir, Work, Disability, and Social Inclusion: The Promise and Problematics of EU Disability Policy, in DeVault (n 12) 81.

19 Rannveig Traustadóttir, Work, Disability, and Social Inclusion: The Promise and Problematics of EU Disability Policy, in ibid.

20 M Del Carmen Martín Cano and YM De La Fuente Robles, "Social Work and Accessibility of Persons with Disabilities in Mexico: Hidden Barriers", Journal of Sociology and Social Welfare, Vol. 45, No.1, March 2018,. p. 212

21 Rannveig Traustadóttir, Work, Disability, and Social Inclusion: The Promise and Problematics of EU Disability Policy, in DeVault (n 12) 90.

\section{B. The Right to Work in Article 27 CRPD: towards an Inclusive Employment}

When the two main conventions, the International Covenant on the Economic Social and Cultural Rights (ICESCR) and the International Covenant on Civil and Political Rights (ICCPR), were established in 1966, ${ }^{22}$ there was no specific mentioning on persons with disabilities as particular of disadvantaged group. Persons with disabilities were grouped in a generic designation of 'other status' in relation to the prohibition of discrimination stated in Article 2 of ICCPR $^{23}$ and ICESCR. ${ }^{24}$ The limits of application of previous human rights treaties in a specific theme acknowledges the need for a specific instrument concerning disability, due to the fact that specified rights of persons with disabilities were insufficiency covered. The fact tells that they are continuing to face barriers to participate in the society and very often being violated..$^{25}$

With regard to the right to work, Article 27 enunciates reasonable accommodation to be guaranteed in the field of employment, particularly in the workplace, ${ }^{26}$ to ensure physical, mental, and social accessibility. The duties of reasonable accommodation is necessary to develop a social-environment that favours the needs and requirements of persons with disabilities due to their specific individual barriers. ${ }^{27}$ This effort is regarded as a form of positive measures in the right to work in order to confer the job-related needs, rather than personal needs (that generally is already

\footnotetext{
22 Adopted and opened for signature, ratification and accession by General Assembly resolution 2200A (XXI) of 16 December 1966 entry into force 3 January 1976, in accordance with article 27.

Art. 2 (1) ibid.

24 Art. 2 (2) 'International Covenant on Economic, Social and Cultural Rights' (1966) < http://www.ohchr.org/EN/ ProfessionalInterest/Pages/CESCR.aspx $>$ accessed 9 June 2016.

25 Preambule $(\mathrm{k})$ 'Convention on the Rights of Persons with Disabilities' < http://www.un.org/disabilities/convention/ conventionfull.shtml $>$ accessed 14 December 2015.

26 Article 27 (1k) 'Convention on the Rights of Persons with Disabilities' <http://www.un.org/disabilities/convention/ conventionfull.shtml $>$ accessed 24 September 2016.

27 Olivia Smith, Disability Discrimination Law, Dublin: Thomson Reuters Round Hall, 2010, p. 217.
} 
equipped by individuals with disability, such as wheelchair, stick, walking support, etc) ${ }^{28}$ and to ensure that specific characteristics attached to certain disability would no longer become a barrier to work, hence their disadvantages can be removed. ${ }^{29}$

CRPD also provides a quota system as a form of positive measures, however such is not clearly defined in terms of certain amount on proportionality and percentage. Article 27 states that this system is intended for inclusive employment that strives to engage a broader involvement of persons with disabilities. It is aimed to ensuring the full participation of persons with disabilities both in private sectors and public sectors. The appropriate steps that need to be taken include "employ persons with disabilities in the public sector" 30 and "to promote in private sector through appropriate policies and measures, which may include affirmative action programmes, incentives and other measures." ${ }^{31}$ An affirmative action is required to secure the participation of persons with disabilities in which a quota system can be supremely conformed to these specific measures. Some countries brought it into domestic laws that endeavour to ensure proportionality of participation of persons with disabilities. Some countries even already settled this quota system far before CRPD being adopted. Disabled veterans post World War II were the group who mostly gained the opportunity of 'quota system' as applied in some countries in Europe, Asia, Africa, the Middle East and Latin America ${ }^{32}$

According to the Committee of CRPD, as suggested in the initial report of Luxembourg (2017), the country is notably required to designate monitoring and sanctioning for noncompliance of quota of persons with disabilities

\footnotetext{
$28 \quad$ Ibid., p. 231.

29 Anna Lawson, Disability and Equality Law in Britain: The Role of Reasonable Adjustment, Oxford; Portland, Or : Hart Pub, 2008, p. 1.

30 Article 27 (1.g) 'Convention on the Rights of Persons with Disabilities' (n 27).

Article 27 (1.h) ibid.

32 Sunwoo LEE and Sookyung LEE, "Comparing Employment Quota Systems for Disabled People Between Korea and Japan”, Asian Journal of Human Services, Vol. 10, , 2016, p. 83-.92. 84 .
}

in private and public sector, as well as monitoring the implementation of reasonable accommodation. ${ }^{33}$

Article 27 is the latest human rights instrument adopted regarding the right to work. ${ }^{34}$ It is intersectionally discussed as a platform of labour theories and disability studies based on human rights issues of dignity and equality that cope with social context of disadvantages. ${ }^{35}$ Moreover, according to Einat Albin, Article 27 "offering a new theoretical direction that deals more adequately with the social context and with personal constraints" since personal constraints are believed as being the cause of denial in open labour market. ${ }^{36}$ It is likely impacted by the medical model of disability that simply perceives disability as a medical/personal problem. Therefore the society tend to 'disabling' persons with disabilities due to 'problem' they pose, as what is called 'abledbodied in mind', ${ }^{37}$ which has caused greater purposive lack of participation in the society.

\section{Crosscutting articles of CRPD linked to} Article 27

\section{In relation with Article 2 (Definitions)}

There are four notions stated in the Article 2: communication, language, discrimination on the basis of disability, reasonable accommodation and universal design. Those four notions, excluding the latter notion of universal design,

\footnotetext{
33 'Commitee on the Rights of Persons with Disabilities: Concluding Observation on the Initial Report of Luxembourg, 10 October 2017, $10<$ http://docstore. ohchr.org/SelfServices/FilesHandler.ashx?enc $=6 \mathrm{QkG1d}$ \%2fPPRiCAqhKb7yhsvP\%2bdTiDrgtVuqxAW\%2b69ti KIXBXKWmNQXT\%2fmo\%2fEyFUOnby\%2frpQIV67B UhoNbCdpCAc7SlOMvANsJafd2PwWE94FABAlKM4 k6zv\%2f6n3fOZNHb>, accessed 31 December 2017.

34 Einat Albin, Universalising the Right to Work of Persons with Disabilities: An Equality and Dignity Based Approach, Hebrew University of Jerussalem Legal Research Paper, No. 15-09, 2015, in ibid 62.

Ibid.,

Ibid.,

Gerard Quinn and Theresia Degener, 'The moral authority for change: human rights values and the worldwide process of disability reform,' in G Quinn, Human Rights and Disability: The Current Use and Future Potential of United Nations Human Rights Instruments in the Context of Disability, United Nations, 2002, p. 15.
} 
are related to Article 27 that provides the right to work for persons with disabilities in particular through positive/preferential treatment.

The positive/preferential measures calls for the undertaking of the efforts to removing barriers of persons with disabilities, in order to enable them to participate on employment sphere. Therefore all mentioned above in article 2, specifically strengthen these needs. Communication definitely supports this purpose. It includes any means of languages, including display of text, braille, tactile communication, large print, accessible multimedia as well as written, audio, plain language, human-reader and augmentative and alternative modes, means and format of communication, and other accessible information and communication technology. ${ }^{38}$ Additionally, any means of languages includes spoken and signed languages and other forms of non-spoken languages. ${ }^{39}$ These are in line with the spirit to provide full supports to any kind of disabilities that form barriers to these peoples, particularly with regard to disabilities in accessing information in a common way. Information is the key to open the door of opportunity, therefore ability to access information is absolutely important to any persons, including persons with disabilities. By providing this support, persons with disabilities, regardless their difficulties or such barriers, can easily access information, so that they would no longer be left behind.

While promoting reasonable accommodation and all supports on means of communication and language to open easier access in a specific manner to deal with certain difficulties faced by persons with disabilities, another salient feature of Article 2 is encouraging a massive universal design. At a glance, it seems contrary with the "the specific way" to accommodate persons with disabilities as previously addressed. Nevertheless universal design is set to apply to all people including

\footnotetext{
38 Article 2, "Convention on the Rights of Persons with Disabilities", No. 27.

39 Article 2, "Convention on the Rights of Persons with Disabilities”, No. 28.
}

persons with disabilities hence eliminates the need for further adjustment.

"Universal design" means the design of products, environments, programmes and services to be usable by all people, to the greatest extent possible, without the need for adaptation or specialized design. "Universal design" shall not exclude assistive devices for particular groups of persons with disabilities where this is needed. ${ }^{40}$

Notwithstanding the spirit of universal design making, in case an assistive device is needed, it should be fulfilled in order to support persons with disabilities in accessing such rights.

Discrimination on the basis of disability is defined in Article 2 as:

any distinction exclusion or restriction on the basis of disability which has the purpose or effect of impairing or nullifying the recognition, enjoyment or exercise, on an equal basis with others, of all human rights and fundamental freedoms in the political, economic, social, cultural, civil or any other field. It includes all forms of discrimination, including denial of reasonable accommodation ${ }^{41}$

Reasonable accommodation in Article 2 means necessary and appropriate modification and adjustments not imposing a disproportionate or undue burden, where needed in a particular case, to ensure to persons with disabilities the enjoyment or exercise on an equal basis with others of all human rights and fundamental freedoms. ${ }^{42}$ Based on this Article, a reasonable accommodation contains three elements: 1 . Appropriate modification and adjustments not imposing a disproportionate or undue burden; 2. Made on case by case basis; and 3. Ensuring enjoyment of human rights and fundamental freedoms.

All these notions in Article 2 cannot be separated from 'accessibility' as stated in Article 9 of the CRPD. Communication, language, prohibition of discrimination on the basis of disability, reasonable accommodation, and

\footnotetext{
40 Article 2, "Convention on the Rights of Persons with Disabilities", No. 27.

Ibid.

42 Ibid.
} 
universal design are all means of accessibility to all rights, including the right to work. General Comment No. 2 explains the key requirement of accessibility to employment that cover physical accessibility in the workplace as well as access to get to the workplace such as via transport and any other necessary support services. ${ }^{43}$ Thereto, all information pertaining to work and communication process including the entire work process must be accessible within the bound forms, modes and formats for persons with disabilities. ${ }^{44}$ Hence refusal for workplace adaptation constitutes a discrimination on the basis of disability. ${ }^{45}$

\section{In relation with Article 5 (Equality and non-discrimination)}

Article 5 of CRPD notes the obligations of the States Parties regarding non-discrimination and equality as the fundamental principles of the human rights law. It is closely interconnected with the notion of dignity as cornerstones of human rights. ${ }^{46}$ Equality and non-discrimination as well as dignity emerge to characterise human rights, which underlie the development of disability model, besides adding State's obligation in the protection and the fulfilment of the rights. In the human rights perspective, persons with disabilities are recognized as rights holders. On the contrary, under medical model of disability, persons with disabilities are merely seen as persons with reduced impairment, whereby a less favourable treatment and exclusion are legitimized, ${ }^{47}$ hence, allowing any restriction and denial of the rights on the basis of impairment. ${ }^{48}$

43 MC Marumoagae, "Disability Discrimination and the Right of Disabled Persons to Access the Labour Market", Potchefstroomse Elektroniese Regsblad, Vol. 15 No 1, 2012, p. 345-428.

44 Para 41, "General Comment No.2 Accessibility, Convention on the Rights of Persons with Disabilities", 2014, accessed 8 April 2018

45 Ibid.

46 Para 4, "General Comment No.6 on Equality and NonDiscrimination of The Convention on the Rights of Persons with Disability", 2018, http://tbinternet.ohchr. org/Treaties/CRPD/Shared\%20Documents/1_Global/ CRPD C GC 68649 E.docx, accessed 28 March 2018.

47 Para 8, Ibid.

48 Para 8, Ibid.
CRPD acknowledges a substantive equality model in confirming 'equality' that moved from a formal model of equality by signifying equalization of opportunities as a general principle under Article 4. Formal equality is designed to oppose direct discrimination by which symmetrical approach is adopted: treating persons in similar situation similarly. ${ }^{49}$ On the other hand, to embrace the different features of human being, substantive equality is set to address structural and indirect discrimination..$^{50}$

Substantive model of equality is adhered to develop an 'inclusive equality' as a new model of equality throughout the $\mathrm{CRPD}^{51}$ which contains:

(a) a fair redistributive dimension to address socio-economic disadvantages; (b) a recognition dimension to combat stigma, stereotyping, prejudice and violence and to recognize the dignity of human beings and their intersectionality; (c) a participative dimension to reaffirm the social nature of people as members of social groups and the full recognition of humanity through inclusion in society; and (d) an accommodating dimension to make space for difference as a matter of human dignity. The Convention is based on inclusive equality. ${ }^{52}$ "

Reasonable accommodation as stated in the Article 5 (3) of the CRPD is the duty of nondiscrimination on the context of disability. ${ }^{53}$ The duty to provide reasonable accommodation consist of two parts: Firstly, imposes obligation to provide modification or adjustment on particular case; Secondly, ensuring that the required accommodation do not impose a disproportionate or undue burden on the duty bearer. $^{54}$

The accommodation might include providing facilities and information; modifying equipment; reorganizing activities; rescheduling work; adjusting curricula learning materials and
Para 10, Ibid.
Para 10, Ibid.
Para 11, Ibid.
Para 11, Ibid.
Para 23, Ibid.
Para 25, Ibid. 
teaching strategies; adjusting medical procedures; or enabling access to support personnel, which are being arranged to ensure accessibility of persons with disabilities without disproportionate or undue burden. ${ }^{55}$ Reasonable accommodation must be provided at the time when persons with disabilities require access to a non-accessible situation or environment. ${ }^{56}$ The duty to provide reasonable accommodation is in individualized case basis at certain time requested. ${ }^{57}$

'Specific measures' should not be regarded as discrimination as it aims to accelerate or achieve de facto equality, ${ }^{58}$ and is considered as positive or affirmative measures by General Comment. ${ }^{59}$ Likewise, this is mentioned in other treaties, such as Article 4 of the Convention on the Elimination of All Forms of Discrimination against Women and Article 1 (4) of the International Convention on the Elimination of All Forms of Racial Discrimination, which entail certain advantages of marginalized group. CRPD is also adopting specific measures to achieve equality in real. The specific measures are usually temporary in nature, but in some circumstances they can also be permanent, ${ }^{60}$ this mostly depends on the needs on dealing with certain structural barriers of the society. ${ }^{61}$

Equality and non-discrimination duties in the context of work and employment are applied in ways of ensuring that any discrimination on the ground of disability in work and employment does not occur. ${ }^{62}$ General Comments No. 6 on Article 5 regarding Equality and Nondiscrimination outlines some steps that should be taken to ensure reasonable accommodation and meanwhile achieve or accelerate de facto equality. ${ }^{63}$ There are some new highlights

\footnotetext{
55 Para 23, Ibid.

56 Article 24 (b), Ibid.

57 Article 24 (b), Ibid.

58 Article 5 (4) 'Convention on the Rights of Persons with Disabilities' (n 27).

59 Para 28 'General Comment No.6 on Equality and NonDiscrimination of The Convention on the Rights of Persons with Disability (2018)' (n 48).

60 Para 28, Ibid.

61 Para 28, Ibid.

62 Para 67, Ibid.

63 Para 67, Ibid.
}

which are specifically mentioned by the General Comment in terms of State obligation, that is to: Facilitating the transition away from segregated work environments to an open labour market and to ensuring the applicability of the rights to those settings; ${ }^{64}$ Promoting the rights of supported employment; and ${ }^{65}$ Paying persons with disabilities no less than the relevant minimum wage and should still be entitled with disability allowance even when they just start to work. ${ }^{66}$ However it is noteworthy that, overall, the general comments elaborate the provisions in article 27 in a different wording and do not necessarily explain the detailed interpretation on the given provisions. ${ }^{67}$

\section{In relation with Article 6 (Women with disabilities)}

General principles on the CRPD recognize equality between men and women, ${ }^{68}$ in particular against multiple discrimination that are more likely beared by women and girls with disabilities during their lives. Article 6 accounts more attention on the protection against intersectional discrimination which might be encountered by women with disabilities due to their multidimensional layers of identities, statuses and life circumstance. ${ }^{69}$ It emphasizes a binding non-discrimination and equality provision for women with disabilities and to promote equality of opportunity and equality of outcomes. ${ }^{70}$ Hence all appropriate measures to ensure full development, advancement and empowerment of women should be taken in order to guarantee equal enjoyment of all

\footnotetext{
64 Para 67 (a), Ibid.

65 Para 67 (b), Ibid.

66 Para 67 (c), Ibid.

67 See Para 67 a-j, Ibid.

68 Article 3 para 7 'Convention on the Rights of Persons with Disabilities' (n 27).

69 See Para 16 'General Comment No. 3 (2016) on Women and Girls with Disabilities, Convention on the Rights of Persons with Disabilities.' < http://docstore.ohchr.org/SelfServices/ FilesHandler.ashx? enc $=6 \mathrm{QkG1d} \% 2 \mathrm{fPPRiCAqhKb} 7 \mathrm{yhsnb}$ HatvuFkZ\%2bt93Y3D\%2baa2oLCHc5Ye5y0yX37Gpo\%2f kmBPRXw7E2EC8F8ZaOYioHwSoKwRuwxjjG2yrOz8CKK 8YelRo89TBHAkq9ze96pPayc> accessed 8 April 2018.

70 Para 9, Ibid.
} 
human rights and fundamental freedom. ${ }^{71}$ For this regard, such measures can be legislative, educational, administrative, cultural, political, linguistic or other nature. ${ }^{72}$ Targeted measures should be set up with respect to disaggregated data collection, consultation, policymaking, the enforceability of non-discrimination policies and the provision of effective remedies. ${ }^{73}$

"Multiple discrimination" as interpreted by General Comment refers to a situation in which a person experiences discrimination on two or more grounds, leading to discrimination that is compounded or aggravated. ${ }^{74}$ While "Intersectional discrimination" refers to a situation where several grounds interact with each other at the same time in such a way as to be inseparable. ${ }^{75}$ Grounds of discrimination, explained by general comment No. 3, include age, disability, ethnic, indigenous group, national or social origin, gender identity, political or other opinion, race, refugee, migrant or asylum seeker status, religion, sex and sexual orientation. ${ }^{76}$

With regard to the right to work, women with disabilities might have certain hindrance to access to employment besides general barriers they undergo insofar. General Comment also mentions "unique barriers" to the equal participation for women with disabilities in workplace including sexual harassment, unequal pay, lack of access to dismissing claims, as well as physical, information and communications barriers. $^{77}$

71 See Article 6 (2) 'Convention on the Rights of Persons with Disabilities' (n 27).

72 Para 20 'General Comment No. 3 (2016) on Women and Girls with Disabilities, Convention on the Rights of Persons with Disabilities.' (n 71).

73 Para 16 ibid.

74 Para 3 (c) ibid Referring to the Committee on the Elimination of Discrimination against Women, general recommendation No. 25 (2004) on temporary special measures, para. 12 .

$75 \quad$ Para 4 (c) ibid Referring to general recommendation No. 28 (2010) on the core obligations of States parties under article 2 of the Convention on the Elimination of All Forms of Discrimination against Women, para. 18.

$76 \quad$ Para 4 (c) ibid.

77 Para 58 (Ibid), and see A/HRC/20/5 and Corr.1, para. 40, and $\mathrm{A} / 67 / 227$, para. 67 .

\section{In relation with Article 19 (Living} independently and being included in the community)

With regard to independent living of persons with disabilities in relation with their right to work, General Comments No. 5 (2017) ${ }^{78}$ elaborates how living independently is applied in Article 27. It pointes out that the existence of individualized support service, including personal assistance, is a precondition for effective enjoyment of the right to work and employment. ${ }^{79}$ In addition, persons with disabilities should also become persons in charge on disability-specific support services, as an employer, manager or trainer. ${ }^{80}$ This also touches the issue of employment on segregated settings, whereby implementing Article 19 (living independently) can help to phase out sheltered employment. ${ }^{81}$

\section{Interlinked with Sustainable Development Goals (SDGs)}

Sustainable Development Goals (SDGs) was launched by the United Nations in 2015 as a continuation of previous Millennium Development Goals (MDGs) that ended in 2015. The time horizon for the SDGs is 15 years: from 2015 to 2030. There are three dimensions of sustainability being addressed by the SDGs (i.e. environmental, economic and social) that are in line with the United Nations global development agenda beyond 2015. ${ }^{82}$

The Preamble of CRPD emphasizes the importance of mainstreaming disability issues as an integral part of relevant strategies of sustainable development. ${ }^{83}$

With regard to relation between disability and SDGs, disability is acknowledged as reference

\footnotetext{
78 'General Comment No. 5 (2017) CRPD on Living Independently and Being Included in the Community' .

Para 91 ibid.

Para 91 ibid.

Para 91 ibid.

'Sustainable Development Goals (SDGs) and Disability | United Nations Enable' < https://www.un.org/ development/desa/disabilities/about-us/sustainabledevelopment-goals-sdgs-and-disability.html> accessed 17 April 2018

83 Preamble (g) 'Convention on the Rights of Persons with Disabilities' (n 27).
} 
particularly in light of education, growth and employment, inequality, accessibility of human settlements, as well as data monitoring of the SDGs. ${ }^{84}$ At least 4 goals reflect the disability rights fulfilment, as described in Goal 4 (Inclusive and equitable equality education), Goal 8 (Promoting sustained, inclusive and sustainable economic growth, full and productive employment and decent work for all), Goal 10 (Promoting social, economic and political inclusion for all), Goal 11 (Inclusive human settlement, safe and sustainable) and Goal 17 (Strengthen the data collection and monitoring), ${ }^{85}$ all of which are necessary to achieve the inclusive society in all aspects.

As mentioned above, the issue of employment also touched upon by SDGs, which is addressed through achieving full and productive employment and decent work for all women and men, including for persons with disabilities, and equal pay of work of equal value. ${ }^{86}$ In this sense, equality is perceived as a means to achieve inclusive society. Meanwhile, Article 27 of CRPD can also be linked to the achievement on Sustainable Development Goals (SDGs), according to the Committee of CRPD in the concluding observation to Ethiopia (2016). Article 27 can guide to achieve target 8.5 of Sustainable Development Goals, ${ }^{87}$ which contains:

By 2030, achieve full and productive employment and decent work for all women and men, including for young people and persons with disabilities, and equal pay for work of equal value.

It also rose on the concluding observation to Latvia ${ }^{88}$ and Luxembourg, ${ }^{89}$ in which the

$84 \quad$ 'Sustainable Development Goals (SDGs) and Disability | United Nations Enable' (n 84).

85 Ibid.

86 Goal 8 ibid.

87 'Commitee on the Rights of Persons with Disabilities: Concluding Observation on the Initial Report of Ethiopia ( 31 August 2016)' (2016) 8.

88 'Commitee on the Rights of Persons with Disabilities: Concluding Observation on the Initial Report of Latvia, 10 October 2017, http://docstore.ohchr.org/SelfServices/ FilesHandler.ashx?enc $=6 \mathrm{QkG1d} \% 2 \mathrm{fPPRiCAqhKb7yhsiyai}$ CIuQzff7FUjD97cNmlMwHPw42Pi74CX9nqtwZb5qlEktw aQ2x8FfTttXJ0XRXWKqzZxg9\%2fh7C25wlyrQ7Z84yHw WFin\%2fZGIu\%2bHYTWea, accessed 31 December 2017.

89 'Commitee on the Rights of Persons with Disabilities: Concluding Observation on the Initial Report of Luxembourg (10 October 2017)' (n 35) 10.
Committee recommends the State Parties to pay attention to the link between Article 27 and Sustainable development Goals in particular on the Goal 8.5.

\section{E. Core elements of the Article 27}

There are some basic elements of Article 27 that are inherently aimed to build a robust protection of the right to work of persons with disabilities:

\section{Dignity Underlying the Right to Work}

The purpose of CRPD is to promote, protect and ensure the full and equal enjoyment of all human rights and fundamental freedoms of all persons with disabilities, and to promote respect for their inherent dignity. ${ }^{90}$ In addition, it centralised on the general principles of inherent dignity, autonomy and independence $;{ }^{91}$ and full and effective participation and inclusion in society. ${ }^{92}$

Article 27 of the Convention highlights the importance of work and employment for persons with disabilities which are weighted on the opportunity to have 'freely chosen and accepted' job in a labour market, by which they gain their independent living. In addition, it is imposing to guarantee the implementation of the rights by state through some appropriate measures. Some of the measures can be sum up as follows: prohibit discrimination; protect just and favourable condition of work including equal opportunity; ensure to exercise labour and trade union rights; enable effective access to employment; promote opportunity of career advancement; promote opportunity for self employment; and employ them in public service as well as in the private sectors; promote their work experience to the open labour market; promote vocational and professional rehabilitation, job retention and return-towork programmes. ${ }^{93}$ Alongside these previous measures, the State Parties should ensure the

\footnotetext{
90 Article 1 'Convention on the Rights of Persons with Disabilities' (n 27).

Article 3 (a) ibid.

Article 3 (c) ibid.

Art.27 of ibid.
} 
employment without slavery or in servitude ${ }^{94}$

As the guidelines for states in the implementation of its duties, the Article is outlining appropriate steps (including legislation), policy and measures, including affirmative action, incentive, and other required measures. ${ }^{95}$ State as safeguarding body has a mandate to conduct, which result will be monitored and reported. ${ }^{96}$ It is not sufficient that person with disabilities being beneficiaries of the services, but the method of monitoring such services must also be set out. Referring to the Article 33 of the Convention, a monitoring process requires 'the establishment or designation of a coordination mechanism within government to facilitate related action in different sectors and at different levels. ${ }^{97}$ In the sense of monitoring process, the involvement of civil society in particular persons with disabilities and their representatives are highly necessitated. ${ }^{98}$ It indicates the inclusiveness of the monitoring process where the involvement of persons with disabilities is fully taken into account. Incorporating persons with disabilities in the monitoring implementation process can ensure the needs of each group of persons with disabilities be well-adapted (most likely based on the type of disability, as each individual encounters different barriers). The disability movements around the world presents the slogan known as: "nothing about us without us" 99 as an empowerment of their voice in all concerns relating to their needs, including the important process of monitoring where they can review to what extent the protection are being provided. This also confirms to what extent the implementation of the Convention, including the right to work on Article 27, is lying down on their best interest and thus ensuring full enjoyment of the right to work.

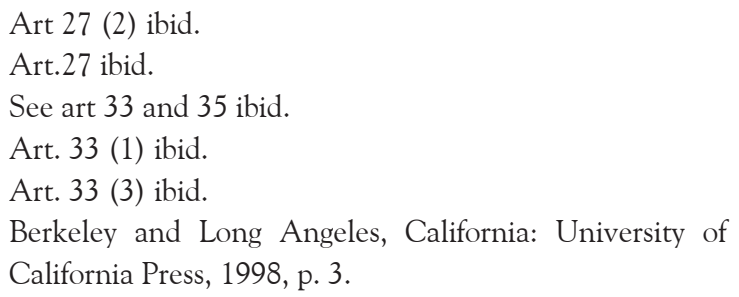

\section{Prohibition of Discrimination in All Forms: Inclusive Employment Setting}

The main point of the CRPD as a human rights instrument is the on these principles of human rights: Equality and Non-discrimination. CRPD stipulates that a denial for reasonable accommodation is a form of discrimination: ${ }^{100}$

\begin{abstract}
"Discrimination on the basis of disability" means any distinction, exclusion or restriction on the basis of disability which has the purpose or effect of impairing or nullifying the recognition, enjoyment or exercise, on an equal basis with others, of all human rights and fundamental freedoms in the political, economic, social, cultural, civil or any other field. It includes all forms of discrimination, including denial of reasonable accommodation.
\end{abstract}

Equality and non-discrimination lie as the fundamental human rights principles underlying the core of all human rights instruments. It is aligned with previous explanation of the Committee on Economic, Social and cultural Rights in General Comment no. 5 on Persons with Disability (1994) on ICESCR stating that "segregation and isolation achieved through the imposition of social barriers" count as discrimination. ${ }^{101}$

With regard to segregation of persons with disability in the employmentarea, the Committee of CRPD suggests to lower the numbers of person with disabilities in a segregated setting, including a sheltered workshop. An open labour market is highly promoted. Based on the Luxembourg initial report, the Committee recommends, with a time-bound schedule and plan, a transfer of those currently employed in sheltered workshops into the open labour market, thus increases the level of employment of persons with disabilities in the open labour market. ${ }^{102}$ Based on initial report of Austria

100 Article 2,"Convention on the Rights of Persons with Disabilities", n. 27.

101 United Nations High Commissioner for Human Rights, 'General Comment No. 5 ICESCR: Persons with Disabilities' (Refworld, 1994), http://www.refworld.org/ docid/4538838fo.html, accessed. 6 April 2017.

102 Commitee on the Rights of Persons with Disabilities: Concluding Observation on the Initial Report of Luxembourg, 10 October 2017, n 35, 10. 
(2013), the Committee of CRPD noted its concern to approximately 19,000 Austrians who work in sheltered workshops outside the open labour market and receive very little pay. ${ }^{103}$ Furthermore, the Committee recommends enhancing programs designed to employ persons with disabilities in the open labour market as well as to narrow the employment and payment gender gap. ${ }^{104}$ In the concluding observation to Latvia (2017), the Committee recommends to ensure support for the employment of all persons with disabilities in the open labour market in inclusive employment setting on an equal basis with others. ${ }^{105}$

\section{Positive Measures Provision}

A broader sense of substantive equality is well captured in the convention, where it enables positive measures to ensure the effective equality for persons with disabilities. The preamble of CRPD mentions "more intensive support" ( $\mathrm{j}$ ), as well as the necessary protection and assistance (x). The Article 2 also emphasises 'reasonable accommodation' to ensure enjoyment or exercise of all human rights and fundamental freedoms on an equal basis with others.

CRPD adopts a concept of substantive equality in defining equality. It defines positive measures as a primary tool to achieve equality. ${ }^{106}$ CRPD mostly adopts the term reasonable accommodation as a form of positive measures duties. Some of the provisions of

103 Commitee on the Rights of Persons with Disabilities: Concluding Observation on the Initial Report of Austria, Adopted by the Commitee at Its Tenth Session, 2-13 September 2013, 7 <http://www.ohchr.org/Documents/ HRBodies/CRPD/10thSession/CRPD-C-AUT-CO-1 en.doc $>$ accessed 31 December 2017.

104 Ibid.

105 Commitee on the Rights of Persons with Disabilities: Concluding Observation on the Initial Report of Latvia (10 October 2017)' (n 90) 9. https://tbinternet.ohchr. org/_layouts/treatybodyexternal/TBSearch.aspx?Lang=e $\mathrm{n} \&$ TreatyID $=4 \&$ DocTypeID $=5$ accessed 31 December 2017.

106 United Nation Development Group, "Including the Rights of Persons with Disabilities in United Nations Programming at Country Level: A Guidance Note for United Nations Country Teams and Implementing Partners", United Nation, 2011, p. 16.
CRPD highlight the state obligation to "take measures" as well as "provide reasonable accommodation", 107 which means that the formal equality as such is insufficiently applied to the context of disability. ${ }^{108}$ Reasonable accommodation, determined as necessary and appropriate modification and adjustment (with reference to "disproportionate or undue burden"), is aimed to ensure enjoyment of the rights of persons with disabilities ${ }^{109}$ individually, or on a case by case basis.

In addition, Article 5 (3) notes the states obligation to take appropriate steps to ensure that reasonable accommodation is provided. This indicates that reasonable accommodation is an important aspect to be taken into consideration, when equalizing disabled persons with nondisabled. In a similar vein, Article 6 (2) brings to light appropriate measures in particular for women with disabilities, and Article 7 (3) points out appropriate assistance for children with disabilities. These arrangements are made due to a potential 'double-discrimination' which might happen to women and children with disabilities, as reflected by the current practice.

\section{Reasonable Accommodation: an Effective Adjustment}

Reasonable accommodation in the Article 27 strengthens the implementation of de-facto equality (substantive equality framework), in coping with a structural discrimination on persons disabilities, by providing certain positive/preferential measures. State's positive measures are necessary, inter alia, to ensure reasonable accommodation being in place, and therefore full participation of persons with disabilities. As reflected in the Article 2, reasonable accommodation aims to ensure that persons with disabilities will get full enjoyment of all human rights and fundamental freedoms

\footnotetext{
107 See Article 5, Article 12, "Convention on the Rights of Persons with Disabilities, n 27.

108 Arlene S. Kanter, The Development of Disability Rights under International Law, Oxon: Routledge, 2014, p. 3.

109 See Article 2 Convention on the Rights of Persons with Disabilities on the definition of 'reasonable accommodation.
} 
on an equal basis with others. Furthermore, reasonable accommodation comprise of three basic elements: Necessary and appropriate modification and adjustments; Not imposing a disproportionate or undue burden; where needed in a particular case by case basis. ${ }^{110}$

Reasonable accommodation deals with individual adjustment that is assessed on a case-by-case basis, thus cannot be delayed in its fulfilment. Accordingly, in this instance, the Committee of CRPD, in the concluding observation to Spain, had clarified that the progressive realization principles does not apply to reasonable accommodation. Reiteration on denial of reasonable accommodation constitutes discrimination, therefore it requires an immediate application. ${ }^{11}$

The notion of 'reasonable accommodation' in the employment context is challenging from time to time. The 'reasonable accommodation' is realised case by case in certain group of persons with disabilities, hence there is always adjustment or modification following the need of the groups concerned. It is a 'tailor made' approach. In some cases, such adjustment is not only 'physical' in nature. In, a workplace that has persons with mental or intellectual disability, consequently the adjustment could also include 'time flexibility', such as to give them a certain 'time break' during the working hours.

Additionally, the implementation of reasonable accommodation could vary in forms, such as: assistive technology, adaptation of work environment, flexible working hours, induction and training ${ }^{112}$ and other possible actions which have burden of cost or even at no cost at all. These arrangements are carried out in order to provide a friendly disability environment to each individual with disability.

\footnotetext{
Article 2 Ibid.

111 Para 44 'Consideration of Reports Submitted by States Parties under Article 35 of the Convention Concluding Observations of the Committee on the Rights of Persons with Disabilities (Sixt Session 19-23 September 2001) to Spain' .

112 Ahead - Accommodations at Work, "Reasonable Accommodations at Work", https://www.ahead.ie/ employer-accommodations, accessed 30 December 2017.
}

It aims to removing barriers; so they can work properly and productively.

Necessary and appropriate modification suggested by the Article 27 implicitly draws the necessity for 'effectiveness' in the adjustment, as suggested by the word 'appropriate' in the Article. ${ }^{113}$ Coping with various types of hindrance with specific degree of disability inevitably requires a personal approach to look for a way that suits best for each individual. It can be done by generating a constructive dialogue ${ }^{114}$ to build a mutual understanding and respecting of inherent dignity of persons with disability.

In addition to the significance of individual approach in providing a reasonable accommodation, CRPD also encourages the use of universal design to a degree. Universal design is applied not only on providing product but also environment friendly for persons with disabilities to the greatest extent possible. However it does not necessarily neglect certain circumstances faced by particular groups of persons with disabilities (including those who need additional assistive devices) ${ }^{115}$ but rather promotes accessibility (to product and environment) in such a way.

\section{Full range of Protection on the Employment Cycle}

Article 27 provides a specific protection on the right to work of persons with disabilities that emphasise on positive measures duties as the state obligation. It purposes to cover full range of protection on the pre-work, during work, and post work. This is to ensure that a greater opportunity for open labour market is fully supported.

\footnotetext{
113 Delia Ferri and Anna Lawson, "Reasonable Accommodation for Disabled People in Employment, a Legal Analysis of the Situation in EU Member States, Iceland and Norway, 2016, 49, https://publications. europa.eu/en/publication-detail/-/publication/ada7afd057ab-4495-8b03-f11757c561f6/language-de, p. 49 accessed 30 December 2017.

114 Ibid.

115 Article 2, Convention on the Rights of Persons with Disabilities, n 27.
} 
The umbrella of the generic right to work of persons with disabilities lied in this Article are the prohibition on discrimination, ${ }^{116}$ the advancement of ensuring reasonable accommodation in the workplace, ${ }^{117}$ and widening of the opportunity to be engaged in both public and private sectors through appropriate policies and measures. ${ }^{118}$ These will be defined in each stage of work-cycle (pre, during, and post employment) as follows:

\section{a. Pre-employment}

The appropriate steps to be taken are firstly, enabling an effective access to general technical and vocational guidance programmes, placement services, and vocational and continuing training. ${ }^{119}$ It can also be organised in the "during-employment cycle", where trainings related to career development are possibly required. Secondly, "promoting employment opportunities and carried out advancement in the labour market, as well as assistance in finding, obtaining, maintaining and returning to employment," ${ }^{120}$ which provide supports to those who are willing to enter a labour force.

Based on Tunisia initial report (2011), the Committee on the Rights of Persons with Disabilities recommends measures of affirmative action being provided to ensure participation of employed women and man with disabilities. ${ }^{121}$ Interestingly, the Committee also concerns on the diversity of the employment and vocational training opportunities. ${ }^{122}$ The diversity of employment and vocational training opportunities is supposed to lead persons with

\footnotetext{
Article 27 (1.a) Ibid.

Article 27 (1.i) Ibid.

Article 27 (1.g) and (1.h) Ibid.

Article 27 (1.d) Ibid.

Article 27 (1.e) Ibid.

Commitee on the Rights of Persons with Disabilities: Concluding Observation of the Commitee on the Rights of Persons with Disabilities to Tunisia, (5thSession 11-15April 2011), 6 http://docstore.ohchr.org/SelfServices/FilesHandler. ashx?enc $=6 \mathrm{QkG1d} \% 2 \mathrm{fPPRiCAqhKb} 7 \mathrm{yhsvOOORvDbzSf}$ y057\%2flfh1RwM0BYu1Nnxrjjo6vZmLus\%2b\%2f1ZDuF iYNWHtW\%2fDL5M9e5FT3JpAI4\%2b19ViOIDUHqW d4WB3yKdk\%2bDJNoe\%2fWjCF1HQ, p. 6 accessed 31 December 2017.
}

122 Ibid. disabilities into a larger possibility to be engaged in a various job opportunities, hence increase an employability in the open labour market as well as self-employment opportunity.

\section{b. During-employment}

Persons with disabilities who are currently being involved in a labour market are protected by the provision of equality "to just and favourable condition of work, including equal opportunities and equal remuneration for work of equal value, safe and healthy working conditions, including protection from harassment and the redress of grievances," 123 and insurance that persons with disabilities can freely and equally exercise their labour and trade union rights. ${ }^{124}$ These arrangements must be conducted in an equal basis, as each type of discrimination (either direct or indirect) on this regard is unlawful. The protection of this cycle of employment engages into generic normative right in work that is generally entitled to all workers. While Article 27 accentuates the specific focus on persons with disabilities to avoid discrimination on the basis of disability in the right to work. Moreover, 'safe and healthy' condition is also important for persons with disabilities. In case a reasonable accommodation is not properly provided to certain individuals with disability, they could possibly suffer from severe condition of health, which can be worse than ill non-disabled workers, due to their particular vulnerability.

\section{c. Post-employment}

This phase covers a post-employment cycle where persons with disabilities, due to some reasons, terminate their employment. It is to "promote acquisition by persons with disabilities of work experience in the open labour market" 125 and to "promote vocational and professional rehabilitation, job retention and return to work programmes for persons with disabilities." ${ }^{126}$ The post-employment protection of persons with disabilities is also dismantling

\footnotetext{
123 Article 27 (1.b), Convention on the Rights of Persons with Disabilities, n 27.

124 Article 27 (1.c), Ibid.

125 Article 27 (1.j) Ibid.

126 Article 27 (1.k) Ibid.
} 
discrimination against persons with disabilities at all stages including in the termination round. Persons with disabilities are entitled to all rights arising from termination of employment in an equal basis with others. Subsequently, the 'return to work programme' is also encouraged by the State authority in order to prevent them from remaining unemployed.

These three classifications of employment cycle are not rigid as such, but rather it could flexibly be permeated on each stage. It can be perceived as a whole cycle that correspond one to another. The important message is on the full protection of the entire cycle of employment, with which the person's disabilities have to deal. They cannot be disregarded, ignored and discriminated due to their disability.

\section{Self-Employment support}

The Convention also recognizes that many disabled persons in developing countries have selfemployment in micro business as their first option, or in some cases the only option. States Parties are called on to promote such opportunities. ${ }^{127}$

Self-employment is another trajectory to uphold independent living for persons with disabilities. Beside the main point to respect the right to self determination on which way favourably chosen by persons with disabilities, it is also to respond the fact that employability in open labour market is still low at the moment ${ }^{128}$ Therefore both promotion of open and selfemployment are highly necessary. Article 27 also highlights the necessity of supporting self-employment for persons with disabilities. As mentioned in the heading of the Article 27 , the realization of right to work shall be safeguarded and promoted, which means that all aspects of the right to work, both access to an open employment and self-employment, have to be covered. The article even profoundly states, "promote employment opportunities for self

127 Arthur O'Reilly, The Right to Decent Work of Persons with Disabilities, Geneva: International Labour Office, 2007, p. 60.

128 Helen Mcquillan, Self-Employment Options For People With Disabilities Good Practice Review, Brothers of Charity Clare, 2012, p. 7. employment, enterpreneurship, the development of cooperative and starting one's own business,"129 which creating a variety of choices for persons with disabilities in the enjoyment of their right to work.

Aligned with the heading of the Article, this provision also emphasises on the roles being taken by state in supporting an open employment. Thus in light of the selfemployment area, there has to be established necessary actions to provide necessary supports tocarry out "promoting opportunities and developing business." As specified in Article 27 (1), States shall take appropriate steps, including through legislation, to protect this right. In addition, a related steps for self-employment must also be granted, such as vocational trainings, grants, access to credit/business loan as well as access to banking services (it can be in a form of microcredit scheme, etc), marketing support, and all possible supports to effectively grow the business, including certain positive steps to open 'captive market' for particular product/services. This concept also aims to support independent living of persons with disabilities, regardless the type of work they wish to enjoy, whether open employment or self-employment.

According in the initial report of Luxembourg (2017), the Committee also pays attention to providing vocational and professional training, and incentives for the self-employment, in particular women with disabilities. ${ }^{130}$ It gives the valued point of view of how a self-employment is remarkable alongside the positive measure duties to support persons with disabilities to open labour market.

\section{Conclusion}

Persons with disability tend to be unemployed. It indicates that persons with disabilities are in a vulnerable situation at which they could be more hit by unemployment, consequently heading to another vulnerability of poverty. On this regard,

\footnotetext{
129 Article 27 (1.f) of Convention on the Rights of Persons with Disabilities, n 27.

130 Commitee on the Rights of Persons with Disabilities: Concluding Observation on the Initial Report of Luxembourg, 10 October 2017, n 35, p. 10.
} 
human rights subsequently play its important role to cope. Strengthening the social model of disability ${ }^{131}$ which are focusing on removing barriers, human rights model of disability also incorporate the state obligation into account, beside dignity, equality, and autonomy to put in place. Accordingly, human rights to emphasize the state obligation to respect, protect, and fulfil the rights, including the right to work.

Convention on the rights of persons with disabilities is the first UN treaty which specifically focusing on person's disability with reference to human rights law. CRPD is focusing on dignity basis in the presence of autonomy towards social inclusion. It is explored on the general principles of Human Rights Based Approach (HRBA) as mentioned in the article 3 of CRPD that respect for inherent dignity, non-discrimination, full and effective participation and inclusion, respect for difference as a part of human diversity and humanity, equality of opportunity, accessibility, equality between men and women, and respect for the evolving capacities of children with disabilities to preserve their identities.

Article 27 frames the state obligation in light of appropriate steps to be taken by the state to ensure the equality of opportunity, inclusive and accessible work for persons with disabilities, including providing reasonable accommodation to achieve de facto equality. It ensures the protection of whole cycle of employment of every person with disabilities which cover pre, during, and post-employment engagement to an open labour market (public and private sectors) with full support by duty bearer. The scope of duties on this regard lies on both open employment and self-employment purposes. Hence all measures taken are going to ensure the opportunity of persons with disabilities to a broader participation in the society on the employment arena.

131 See also Rafael De AsíS Roig and others, "The Impact of the International Convention on the Rights of Persons with Disabilities on Qatari Domestic Legislation", The Age of Human Rights Journal, No. 8, 2017, p. 1-17, http:// revistaselectronicas.ujaen.es/index.php/TAHRJ/article/ view/3459, accessed 2 October 2018.

\section{Bibliography}

\section{Journal Articles}

Cano. M Del Carmen Martín and YM De La Fuente Robles. "Social Work and Accessibility of Persons with Disabilities in Mexico: Hidden Barriers". Journal of Sociology and Social Welfare, Vol. 45, No. 1, March 2018.

De AsíS. Rafael. and others. "The Impact of the International Convention on the Rights of Persons with Disabilities on Qatari Domestic Legislation”. The Age of Human Rights Journal. No. 8. 2017.

Joly. Eduardo Daniel and María Pía Venturiello. "Persons with Disabilities: Entitled to Beg, Not to Work. The Argentine Case". Journal of Critical Sociology. Vol. 39 Issue 3. July 2012.

Kanter. AS. "A Comparative View of Equality Under the UN Convention on the Rights of PERSONS with Disabilities and the Disability Laws of the United States and Canada". Windsor Yearbook of Access to Justice. Vol. 32. 2015.

LEE. S. and Sookyung Lee. "Comparing Employment Quota Systems for Disabled People Between Korea and Japan". Asian Journal of Human Services. Vol.10. April 2016.

Lysaght. Rosemary and others. "Inclusion Through Work and Productivity for Persons with Intellectual and Developmental Disabilities". Journal of Applied Research in Intellectual Disabilities,.Vol. 30. 2017.

MC. Marumoagae. "Disability Discrimination and the Right of Disabled Persons to Access the Labour Market". Potchefstroomse Elektroniese Regsblad. Vol. 15 No 1. 2012.

Rose. Helena. Daiches A. and Potier J. "Meaning of Social Inclusion to Young People Not in Employment, Education or Training". Journal of Community and Applied Social Psychology. Vol. 22. Issue 3. May/June 2012. 


\section{Books}

Charlton, James I. Nothing about Us Without Us: Disability Oppression and Empowerment. Kota Terbit: University of California Press. 1998.

Ferri, D and Lawson A. Reasonable Accommodation for Disabled People in Employment, a Legal Analysis of the Situation in EU Member States, Iceland and Norway. .2016. https://publications.europa. $\mathrm{eu} / \mathrm{en} / \mathrm{publication}$-detail/publication/ ada7afd0-57ab-4495-8b03-f11757c561f6/ language-de. accessed 30 December 2017.

Jaeger. Paul T and Bowman CA. Understanding Disability: Inclusion, Access, Diversity, and Civil Rights. London: Greenwood Publishing Group, 2005.

Kanter, Arlene S. The Development of Disability Rights under International Law. Oxon: Routledge. 2014.

Lawson, Anna. Disability and Equality Law in Britain. The Role of Reasonable Adjustment, Oxford; Portland, Or. Hart Pub. 2008.

Marjorie L, DeVault (ed). People at Work: Life, Power, and Social Inclusion in the New Economy. New York: NYU Press. 2008.

Mcquillan. Helen. Self-Employment Options For People With Disabilities Good Practice Review.Brothers of Charity Clare. 2012.

Smith, Olivia. Disability Discrimination Law. Kota Terbit: Thomson Reuters Round Hall. 2010.

O'Reilly, Arthur. The Right to Decent Work of Persons with Disabilities. Geneva: International Labour Office. 2007.

\section{International Instruments}

United Nation, 'General Comment No.18 on International Covenant on Economic, Social and Cultural Rights'.

United Nations High Commissioner for, 'General Comment No. 5 ICESCR: Persons with Disabilities'. Refworld. 1994. http:// www.refworld.org/docid/4538838fo.html.
'The Universal Declaration of Human Rights. United Nations. (1948) <http://www. un.org/en/universal-declaration-humanrights/. accessed 15 April 2016.

'International Covenant on Economic, Social and Cultural Rights'. 1966 http://www. ohchr.org/EN/ProfessionalInterest/Pages/ CESCR.aspx. accessed 16 April 2016.

'OHCHR | International Convention on the Elimination of All Forms of Racial Discrimination'.http://www.ohchr.org/EN/ Professionalinterest/Pages/CERD.aspx. accessed 23 December 2017.

'Convention on the Rights of Persons with Disabilities' .http://www.un.org/disabilities/ convention/conventionfull.shtml. accessed 24 September 2016.

'Convention on The Rights of Persons with Disabilities'. no date. http://www.un.org/ disabilities/convention/conventionfull. shtml. accessed 14 December 2015.

'General Comment No.6 on Equality and NonDiscrimination of The Convention on the Rights of Persons with Disability (2018)'.

'International Covenant on Civil and Political Rights'. no date http://www.ohchr.org/ en/professionalinterest/pages/ccpr.aspx. accessed 25 October 2016.

'International Covenant on Economic, Social and Cultural Rights'. http://www.ohchr. org/EN/ProfessionalInterest/Pages/CESCR. aspx. accessed 9 June 2016.

'General Comment No.2 (2014) Accessibility, Convention on the Rights of Persons with Disabilities'.

'General Comment No. 3 (2016) on Women and Girls with Disabilities, Convention on the Rights of Persons with Disabilities.' (no date).

'General Comment No. 5 (2017) CRPD on Living Independently and Being Included in the Community'. 
Sustainable Development Goals (SDGs) and Disability | United Nations Enable'. no date.https://www.un.org/development/ desa/disabilities/about-us/sustainabledevelopment-goals-sdgs-and-disability. html. accessed 17 April 2018.

\section{Others}

Commitee on the Rights of Persons with Disabilities: Concluding Observation on the Initial Report of Ethiopia ( 31 August 2016)'.

Commitee on the Rights of Persons with Disabilities: Concluding Observation on the Initial Report of Latvia (10 October 2017)'.

Commitee on the Rights of Persons with Disabilities: Concluding Observation on the Initial Report of Luxembourg (10 October 2017)'.

Commitee on the Rights of Persons with Disabilities: Concluding Observation on the Initial Report of Austria, Adopted by the Commitee at Its Tenth Session, 2-13 September 2013'.

Consideration of Reports Submitted by States Parties under Article 35 of the Convention Concluding Observations of the Committee on the Rights of Persons with Disabilities (Sixt Session 19-23 September 2001) to Spain'.
Commitee on the Rights of Persons with Disabilities: Concluding Observation of the Commitee on the Rights of Persons with Disabilities to Tunisia (5th Session 11-15 April 2011)'.

Including the Rights of Persons with Disabilities in United Nations Programing at Country Level: A Guidance Note for United Nations Country Teams and Implementing Partners. United Nation Development Group. 2011. https://www.google.com/search?q=Inclu ding + the + Rights + of + Persons + with + Disabilities + in + United +Nations + + Pro gramming + at + Country + Level $\% 3 \mathrm{~A}+\mathrm{A}$ + Guidance + Note + for + United + Natio ns + Country + Teams + and + Implementin $\mathrm{g}+$ Partners. + United + Nation + Developm ent + Group $+(2011) \& i e=u t f-8 \& o e=u t f-$ $8 \&$ client $=$ firefox $-\mathrm{b}$. acessed 13 April 2107

Ahead - Accommodations at Work. no date. "Reasonable Accommodations at Work", https://www.ahead.ie/employeraccommodations. accessed 30 December 2017. 